\title{
Legumes Alone and in Combination with Manure as Fertilizers in an Intensive Muskmelon Production System
}

\section{Wilfred Singogo ${ }^{1}$, William J. Lamont, Jr. ${ }^{2}$, and Charles W. Marr Department of Horticulture, Kansas State University, Manhattan, KS 66506}

Additional index words. Cucumis melo, Medicago sativa, Vicia villosa, Pisum sativum subsp. arvense, plastic mulch, drip irrigation

Before the advent of inorganic fertilizers, vegetable producers routinely used considerable amounts of livestock manures, soilimproving legumes in rotation with vegetables and other agronomic crops, and green manures in their farming operations (Kelly, 1990). The development of specialized farming operations in the Central Plain states has resulted in large commercial feed lots that produce an abundance of manure. If not used or stored properly this manure can pollute groundwater and cause other detrimental environmental consequences.

Pollution of groundwater, lakes, and streams by nitrates and phosphorus from inorganic fertilizers has been well documented (Porter, 1975). These problems have contributed to a renewed interest in crop production systems that use organic sources of fertilizers. We, therefore, determined the feasibility of producing netted muskmelons (Cucumis melo L.) using over-wintering legumes or winter wheat alone and in combination with animal manures while incorporating positive aspects of drip irrigation and plastic mulches (Lay and Wells, 1975; Schales and Sheldrake, 1965; Shmueli and Goldberg, 1971; Waggoner et al., 1960).

The experiment design was a split plot with main plots of legumes [alfalfa (Medicago sativa L. cv. Kansas Common), hairy vetch (vicia villosa Roth), and Austrian winter pea (Pisum sativum subsp. arvense L. Poir)] and winter wheat (Triticum aestivum L. cv. Tam 107) seeded at- 33, 33, 72, and $44 \mathrm{~kg} \cdot \mathrm{ha}^{-1}$, respectively, 22 Sept. 1989 on a Hayne fine

Received for publication 8 Mar. 1991. Contribution no. 99-333-J of the Kansas Agricultural Experiment Station. Reference to a product does not imply recommendation to the exclusion of others that may be suitable. The cost of publishing this paper was defrayed in part by the payment of page charges. Under postal regulations, this paper therefore must be hereby marked advertisement solely to indicate this fact.

Graduate Student.

${ }^{2}$ Assistant Professor.

${ }^{3}$ Professor. sandy loam soil. On 3 May 1990, feed' lot cow manure was applied to half of each main plot at $10 \mathrm{t} \cdot \mathrm{ha}^{-1}$. The field had been in soybeans during the summer before beginning the experiment. The soil was plowed, disked, and prepared for bedding before application of the plastic mulch and drip irrigation tubing. Control plots received no treatment or a complete fertilizer at 70,100, and $135 \mathrm{~kg}$ $\mathrm{N}, \mathrm{P}$, and $\mathrm{K} / \mathrm{ha}$ before bedding the soil. On 28 May 1990, 31- $\mu$ m-thick, 1.2-m-wide, black, embossed mulch film and drip irrigation tape $(0.20 \mathrm{~mm}$ thick, emission spacing $30 \mathrm{~cm}$, flow rate of 1.5 liters $\cdot \mathrm{min}^{-1} \cdot 30$ $\mathrm{m}^{-1}$ of row at $55 \mathrm{kPa}$ ) (Roberts Irrigation Products, San Marcos, Calif.) were applied using standard commercial practices. Each main plot consisted of three plastic-covered, 22-m-long rows on 1.5-m centers. 'Magnum. $45^{\prime}$ muskmelon transplants were grown in $24-\mathrm{cm}^{3}$ cells for 4 weeks in a greenhouse and transplanted $45 \mathrm{~cm}$ apart on 31 May 1990. Soil water status was measured with tensiometers at $15-$ and $30-\mathrm{cm}$ depths, and water

Table 1. Influence of fertilizer source on 'Magnum.45' muskmelon yields.

\begin{tabular}{|c|c|c|c|}
\hline \multirow[b]{2}{*}{ Source } & \multicolumn{2}{|c|}{ Fruit yield } & \multirow{2}{*}{$\begin{array}{l}\text { Mean } \\
\text { fruit wt } \\
\text { (kg) }\end{array}$} \\
\hline & $\begin{array}{l}\text { (no./ha, } \\
\text { thousands) }\end{array}$ & $\left(\mathrm{t} \cdot \mathrm{ha} \mathrm{a}^{-1}\right)$ & \\
\hline \multicolumn{4}{|l|}{ Organic } \\
\hline Alfalfa & 55.2 & 85.2 & 1.40 \\
\hline Alfalfa + manure & 59.8 & 96.8 & 1.47 \\
\hline Hairy vetch & 50.4 & 72.2 & 1.30 \\
\hline \multicolumn{4}{|l|}{ Hairy vetch +} \\
\hline manure & 58.4 & 92.0 & 1.43 \\
\hline Austrian winter pea & 54.0 & 79.2 & 1.33 \\
\hline \multicolumn{4}{|l|}{ Austrian winter } \\
\hline pea + manure & 54.6 & 83.1 & 1.38 \\
\hline Wheat & 51.8 & 77.1 & 1.35 \\
\hline Wheat + manure & 54.8 & 85.2 & 1.41 \\
\hline \multicolumn{4}{|l|}{$\begin{array}{l}\text { Synthetic } \\
\mathrm{N}\left(\mathrm{kg} \cdot \mathrm{ha}^{-1}\right)\end{array}$} \\
\hline 0 & 48.4 & 67.2 & 1.26 \\
\hline 70 & 52.4 & 78.6 & 1.36 \\
\hline 100 & 58.6 & 88.5 & 1.37 \\
\hline 135 & 59.6 & 94.6 & 1.44 \\
\hline LSD 0.05 & NS & 7.39 & 0.08 \\
\hline
\end{tabular}

was applied when the soil water potential at $15 \mathrm{~cm}$ reached $-0.25 \mathrm{kPa}$.

Melons were harvested 15 times, beginning on 27 July and ending on 31 Aug. 1990. Weight and number of marketable fruit were recorded.

The addition of cow manure increased the total weight of melons per hectare over the legumes or winter wheat alone (Table 1). The highest yield (nearly $97 \mathrm{t} \cdot \mathrm{ha}^{-1}$ ) was obtained from alfalfa + manure, which was similar to that from the highest rate of synthetic fertilizer. Total weight of melons increased as the amount of synthetic fertilizer increased to $135 \mathrm{~kg} \mathrm{~N} / \mathrm{ha}$, similar to findings of Bhella and Wilcox (1986) and W.J.L. et al. (unpublished data). There were some statistical differences in the fruit weight, but these were not of practical significance. Yields obtained with the legumes alone (Table 1), although lower than those with legumes plus manure, still were commercially satisfactory. Biomass production for alfalfa, hairy vetch, Austrian winter pea, and wheat on a dry-weight basis was 2800, 5600, 3200, and $4900 \mathrm{~kg} \cdot \mathrm{ha}^{-1}$, respectively. They all provided excellent ground cover by 3 May and were winter hardy. The $\mathrm{N}$ content was $3.8 \%$, $4.1 \%, 3.3 \%$, and $1.6 \%$, respectively. Problems associated with using manure for production of vegetables, as described by Kelly, 1990), may offset the improved yields. The advantage of using fall-planted and overwintered legumes for an annual crop may appeal to many vegetable growers who find the more traditional 3- to 4-year rotation with legumes unacceptable. The use of legumes coupled with drip irrigation and plastic mulches may offer a new cropping system that can produce high yields and protect the environment.

\section{Literature Cited}

Bhella, H.S. and G.E. Wilcox. 1986. Yield and composition of muskmelons as influenced by preplant and trickle applied nitrogen. HortScience 21:86-88.

Kelly, W.C. 1990. Minimal use of synthetic fertilizers in vegetable production. HortScience 25:168-169.

Lay, J.B. and O.S. Wells. 1975. Response of hybrid muskmelons to polyethylene row covers and black polyethylene mulch. Scientia Hort. 3:223-230.

Porter, K.S. 1975. Nitrogen and phosphorus-Feed production, waste and the environment. Ann Arbor Science, Ann Arbor, Mich.

Schales, F.D. and R. Sheldrake. 1965. Mulch effects on soil conditions and muskmelon response. Proc. Amer. Soc. Hort. Sci. 88:425430.

Schmueli, M. and D. Goldberg. 1971. Sprinkler, furrow and trickle irrigation of muskmelon in an arid zone. HortScience 6:557-559.

Waggoner, P.E., P.M. Miller, and H.C. DeRoo. 1960. Plastic mulching, principles, and benefits. Connecticut Agr. Expt. Sta. Bul., New Haven. 634:124-128. 